\title{
Licensing of Chlorine Gas Infusion Applicators in Florida ${ }^{1}$
}

\author{
Frederick M. Fishel ${ }^{2}$
}

This document explains the licensing and regulation of persons who use a portable infusion system to treat water with chlorine gas in Florida, as regulated by the Florida Pesticide Law (Chapter 487), and administered by the Florida Department of Consumer Services.

\section{Chlorine Gas Infusion}

All persons who use or supervise the use of chlorine gas to treat water in residential swimming pools by means of a portable system must have a pesticide applicator license issued by the Bureau of Compliance Monitoring/Pesticide Certification Section. Persons licensed in this category are authorized to use only those chlorine gas products specifically registered by the EPA and FDACS with label directions for application to residential swimming pools. Individuals who conduct or supervise water treatment using machinery permanently attached to all pools are exempt from this licensure requirement. This category is valid for licensure of commercial applicators. The Chlorine Gas Infusion category is regulated by the Florida Pesticide Law (Florida Statutes, Chapter 487).

\section{Category Certification Standards}

Applicators seeking a license in this category must demonstrate practical knowledge of the safe handling and application of liquefied chlorine gas for treatment of swimming pools, hot tubs and spas. This will include a knowledge of:

- the toxicity of liquefied chlorine gas;

- the dispersion properties and other characteristics of gaseous chemicals;

- equipment types;

- calibration procedures;

- application techniques;

- air and water monitoring procedures;

- use and maintenance of personal protective equipment and clothing; and

- factors that may lead to a hazardous condition, including handling of pressurized chemicals and direct or continuous exposure to chlorine gas.

\section{License classification}

Certified chlorine gas infusion applicators are licensed as commercial applicators.

1. This document is PI-153, one of a series of the Pesticide Information Office, Florida Cooperative Extension Service, Institute of Food and Agricultural Sciences, University of Florida. Original publication date June 2007. Visit the EDIS Web Site at http://edis.ifas.ufl.edu.

2. Frederick M. Fishel, associate professor, Agronomy Department, and Director, Pesticide Information Office; Florida Cooperative Extension Service, Institute of Food and Agricultural Sciences, University of Florida, Gainesville, FL 32611.

The use of trade names in this publication is solely for the purpose of providing specific information. UF/IFAS does not guarantee or warranty the products named, and references to them in this publication does not signify our approval to the exclusion of other products of suitable composition. Use pesticides safely. Read and follow directions on the manufacturer's label.

The Institute of Food and Agricultural Sciences (IFAS) is an Equal Opportunity Institution authorized to provide research, educational information and other services

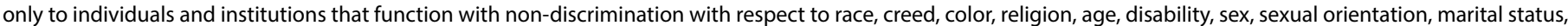

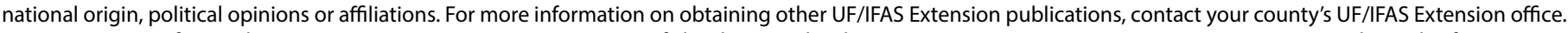
U.S. Department of Agriculture, UF/IFAS Extension Service, University of Florida, IFAS, Florida A \& M University Cooperative Extension Program, and Boards of County Commissioners Cooperating. Nick T. Place, dean for UF/IFAS Extension. 
- A commercial applicatorylicensedein the chterimetigas see http://edis. ifas. ufl. edu or your local extension office. infusion category is licensed to apply only those chlorine gas products specifically registered by the EPA and University of Florida/IFAS Pesticide Information Office, FDACS with label directions for application to residential swimming pools. A commercial applicator is usually a contract applicator. The commercial applicator fee for a four-year license is $\$ 200$.

\section{Examinations}

Persons must successfully complete the chlorine gas infusion examination before they can apply to the Department for a license.

The chlorine gas infusion examination is administered by FDACS - Division of Agricultural Environmental Services. The chlorine gas infusion examination may be scheduled by calling the FDACS Pesticide Certification Section at (850) 488-3314. No special qualifications must be met to take the examination. There is no fee to take the examinations.

\section{Study materials}

Study materials for the chlorine gas infusion examination may be obtained from the FDACS Pesticide Certification Section by calling (850) 488-3314. Sample labels may be obtained from suppliers of chlorine gas infusion products.

\section{Recertification}

Applicators must recertify every four years. To recertify, applicators may take the examination again or attend training and obtain 4 continuing education units (CEUs) approved for the chlorine gas infusion category and 4 CEUs approved for the Core category. Core CEUs can't be used to meet the required chlorine gas infusion CEUs. No substitutions of other types of CEUs are allowed. Opportunities to earn CEUs may be found at http://www.flaes.org/

\section{Products applied in the chlorine gas infusion category}

A current list of chlorine gas infusion products registered in Florida may be viewed at http://state.ceris.purdue.edu/doc/ fl/statefl.html

\section{Additional information}

Florida Department of Agriculture and Consumer Services Bureau of Compliance Monitoring, Pesticide Licensing Section, 3125 Conner Drive, Bldg. 8, L-29, Tallahassee, FL 32399-1650, Phone: 850-488-3314, http://www.flaes.org/ complimonitoring/index.html (accessed July 22, 2010). 